activities. During the hundred years of its existence, the Office has played a large part in fostering international co-operation in meteorology, and the late Sir Nelson Johnson was president of the International Meteorological Organization during the critical postwar period when the Organization handed over its responsibilities to the World Meteorological Organization, one of the Specialized Agencies of the United Nations. The staff of the Office take a large part in the activities of the World Meteorological Organization, especially in relation to its technical commissions, and the meteorologist has to accept foreign travel as an integral part of his official duties.

The greatest handicap from which the Meteorological Office has suffered during its first hundred years has been the neglect of meteorology as a subject for systematic study by British universities generally ; but there are now welcome signs of an awakening of interest. The Office has placed research contracts with the universities of Oxford, Cambridge, London and Wales (University College, Aberystwyth), and has stimulated interest in the science by inviting members of university staffs to serve on the Meteorological Research Committee. The need for basic study is, however, pressing, and although the Office has now a large and well-developed research side, backed by one of the finest collections of meteorological literature in the world, the professional meteorologist requires more than ever the support of the academic worker to help him to grapple effectively with the many problems that await solution.

\section{THE GOVERNMENT LABORATORY POLONIUM SERVICE}

$\mathrm{I}^{\mathrm{N}}$

April 1930, Dr. (now Sir George) G. C. Simpson, then director of the Meteorological Office (Air Ministry), approached Sir Robert Robertson, who was Government Chemist at the time, with the request that the Government Chemist's Department should undertake the polonium plating of the 'collectors' of the instruments used for measuring atmospheric potential gradient at the observatories at Kew, Eskdalemuir, Dumfriesshire and Lerwick, Shetland.

The 'collectors' are copper rods, 3 in. long tapped to a 2.B.A. thread at one end, and they are plated with polonium for about half an inch at the other end. The originals were supplied by the. Meteorological Office, but replacements have since been made in the Government Laboratory workshop. Experimental work has also been carried out with a split collector, plated over a narrow band in the middle of a cylinder 2 in. long, and $\frac{3}{8}$ in. in diameter, that is made in two pieces for elipping on to a wire. In use, the standard type of collector is screwed to a rod projecting from the wall of a building, the rod being connected to the needle of a quadrant-type electrometer.

The record is standardized by measurements over open level ground. Before the introduction of the polonium-coated type, Kelvin 'water drop' electrodes were used at Kew and Eskdalemuir, and a spiral wire coated with a preparation containing radium at Lerwick. Potential gradient measurements have been made at Kew since about 1840 , and the record is tabulated since 1898. The quadrant electrometer in use at present was set up in 1886 ; it is a slight modification of a very early model installed personally by Lord Kelvin in 1873 .

Prof. Sidney Russ, of the Middlesex Hospital, supplied the Government Chemist's Department with used radon tubes, and from them Mr. C. O. Harvey prepared the plating solutions as radium $\mathrm{D}, \mathrm{E}$ and $\mathrm{F}$ in $N / 2$ (5 per cent) hydrochloric acid; though since 1935 the solutions have been made up in $0.15 \mathrm{~N}$ ( 1 per cent) nitric acid, which was found to be more satisfactory. On May 9, 1930, the first collector was dispatched to Kew Observatory, and since then more than four hundred collectors have been sent to the observatories at Kew, Lerwick and Eskdalemuir. The work, originally in the care of Mr. Harvey, has since been performed by Mr. J. L. Buchan, Dr. P. J. Hardwick, Dr. C. R. Hoskins and Mr. A. D. BaynesCope in succession.

The techniques used are kept as simple as possible. Plating is by autodeposition, during $24 \mathrm{hr}$., from a magnetically stirred solution. Each of the six solutions used contains about $\frac{1}{2}$ mc. of radium D and is used about once every three months, allowing ample time for polonium to be regenerated from the radium D. Copper accumulates in the solutions, and is removed every two years.

The service was not interrupted in any way by the Second World War, and the only recorded mishap came in January 1953, when the collector in use at Lerwick was blown away in a blizzard. A fresh collector was dispatehed within twenty-four hours, and later, the collector was recovered, bent but still active and serviceable.

During 1954, information on the length of useful service was obtained from the observatories, and experimental data were obtained in the Government Chemist's Department. It was found that the loss of efficiency in collectors was due more to adverse weather conditions than to normal radioactive decay processes. The fog of December 1952 almost completely deactivated the collector at Kew, whereas in fine weather in the spring in 1954 the Lerwick collector lost only a little more than the theoretical amount of activity.

This account is published by permission of the Government Chemist, Dr. G. M. Bennett.

\section{DEPARTMENT OF SCIENTIFIC AND INDUSTRIAL RESEARCH REPORT FOR 1953-54}

TF the persistence with which questions have been 1 asked in the House of Commons in recent months concerning the Department of Scientific and Industrial Research is any guide, the Department's report for the year 1953-54* should be received with exceptional interest. It includes a short report of the Committee of the Privy Council, over Lord Salisbury's signature, and the thirty-ninth annual report of the Advisory Council, signed by Sir Hugh Beaver; there is also the usual summary of work carried out by the various research stations and boards and research associations--in fact, the report follows the usual patterm of recent years. Besides a summary of the Department's expenditure for the * Department of Scientific and Industrial Research. Report for the
year 1953-54. (Cmd. 9386.) Pp. 326. (London: H.M. Stationery Office, 1955.) 98 . net. 